Int. J. Electrochem. Sci., 16 (2021) Article ID: 21036

International Journal of

ELECTROCHEMICAL

SCIENCE

$\underline{\text { www.electrochemsci.org }}$

\title{
Study of the Novel Ni/Co-SiC Coatings Deposited by Pulse Current Electrodeposition. Influence of the Pulse Frequency and the Duty Cycle
}

\author{
Xinlong $Y u^{1, *}$, Zhipeng $M a^{1}$, Jun $\mathrm{Li}^{2}$, Chunyang $M a^{1}$ \\ ${ }^{1}$ College of Mechanical Science and Engineering, Northeast Petroleum University, Daqing 163318, \\ China; \\ ${ }^{2}$ State Grid Integrated Energy Service Group Co. LTD, Beijing 100052, China \\ *E-mail: xhy5913@163.com (Dr.X.Yu)
}

doi: $10.20964 / 2021.03 .64$

Received: 20 November 2020 / Accepted: 10 January 2021 / Published: 31 January 2021

\begin{abstract}
$\mathrm{Ni} / \mathrm{Co}-\mathrm{SiC}$ coatings were successfully deposited on mild steel via pulse current electrodeposition (PCE) technique. The impact of the frequency and duty cycle on the coating characteristics, such as surface morphology, the orientation of grains, crystal size, micro-hardness, the amount of deposited SiC CNPs, as well as corrosion resistance, were ascertained and discussed. The results indicate that the SiC particles tend to agglomerate, leading to the formation of particle clouds, having mean dimensions of approximately $116.1 \mathrm{~nm}$, enveloped as second phases in the matrix of $\mathrm{Ni} / \mathrm{Co}$ coating. The $\mathrm{Ni} / \mathrm{Co}-\mathrm{SiC}$ coating created at a duty cycle of $10 \%$ and $10 \mathrm{~Hz}$ pulse frequency was able to process the maximal $\mathrm{SiC}$ content equivalent to $11.5 \mathrm{v} / \mathrm{v} \%$. It also illustrates that, with the increment in pulse frequency or decrease in duty cycle, the coating grain assumes a smaller size. The $\mathrm{Ni} / \mathrm{Co}-\mathrm{SiC}$ coating synthesized at a duty cycle of $10 \%$ and $10 \mathrm{~Hz}$ pulse frequency manifest the maximum micro-hardness value of $672.5 \mathrm{~kg} / \mathrm{mm}$, and the $\mathrm{Ni} / \mathrm{Co}-\mathrm{SiC}$ coating deposited at $20 \mathrm{~Hz}$ and $30 \%$ has the maximum micro-hardness value of 642.2 $\mathrm{kg} / \mathrm{mm}$. In addition, the resistance of charge-transfer at the electrode/solution is known to affect the size of the semicircle, hence the size increases with the increment in pulse frequency and decrease in duty cycle.
\end{abstract}

Keywords: $\mathrm{Ni} / \mathrm{Co}-\mathrm{SiC}$ coating; pulse frequency; duty cycle; surface morphology; corrosion resistance

\section{$\underline{\text { FULL TEXT }}$}

(C) 2021 The Authors. Published by ESG (www.electrochemsci.org). This article is an open access article distributed under the terms and conditions of the Creative Commons Attribution license (http://creativecommons.org/licenses/by/4.0/). 